\title{
Stolen motherhood-case study of postpartum depression
}

\author{
Skradzione macierzyństwo-studium przypadku depresji poporodowej
Aneta Gerhant ${ }_{\mathrm{A}, \mathrm{B}, \mathrm{D}, \mathrm{E}, \mathrm{F}, \text { Marcin Olajossy }}^{1}{ }_{\mathrm{A}, \mathrm{D}, \mathrm{F} \text {, }}$ Agata Kalińska ${ }_{\mathrm{B}, \mathrm{F}}$, Agata Miernicka ${ }_{\mathrm{B}, \mathrm{F}}$

1. $2^{\text {nd }}$ Department of Psychiatry and Psychiatric Rehabilitation Medical University of Lublin, Poland

\begin{abstract}
Aim: The objective was to analyze the case of postpartum depression complicated with extended suicide attempt.

Method: The analysis of clinical case and medical history.

Results: In 25-year-old patient, two weeks after childbirth, postpartum depression episode occurred. In the further course of illness psychotic symptoms (delusions, mood disorders), suicidal and infanticide thoughts emerged. Four weeks after childbirth, the patient killed her baby and took an unsuccessful suicidal attempt. Based on medical records, several risk factors of postpartum depression were identified: 1 . obstetric and child-related risk factors: Caesarean section, premature birth, obstetric complications during pregnancy, infant's difficult temper, difficulties related to breastfeeding; 2. psychological risk factors: baby blues, high anxiety level during pregnancy, high level of stress related to child care.

Conclusions: Psychoeducation of women during pregnancy, including their families, is an extremely crucial element of postpartum depression prevention. It is also necessary to raise awareness among healthcare professionals who have frequent contact with mothers after childbirth: midwives, gynaecologists and paediatricians.
\end{abstract}

Keywords: postpartum depression, perinatal depression

\section{Streszczenie}

Cel: Celem pracy jest analiza przypadku depresji poporodowej z objawami psychotycznymi, powikłanej próbą samobójstwa rozszerzonego.

Metody: Analiza przypadku klinicznego i dokumentacji medycznej pacjenta.

Wyniki: U 25 letniej pacjentki, dwa tygodnie po urodzeniu dziecka, wystąpił epizod depresji poporodowej. W dalszym przebiegu choroby dołączyły się objawy psychotyczne (urojenia zgodne z nastrojem), myśli samobójcze oraz dotyczące zabicia dziecka w ramach samobójstwa rozszerzonego. Cztery miesiące po porodzie pacjentka zabiła swoje dziecko, a następnie podjęła nieudaną próbę samobójczą. Na postawie wywiadu zidentyfikowano u badanej szereg czynników ryzyka depresji poporodowej:1. położnicze i związane z dzieckiem: poród przez cięcie cesarskie, wcześniactwo, komplikacje położnicze w okresie ciąży, trudny temperament dziecka, problemy z karmieniem piersią; 2. psychologiczne: smutek poporodowy, wysoki poziom lęku w okresie ciąży, wysoki poziom stresu związanego z opieką nad dzieckiem.

Wnioski: Ważnym elementem prewencji depresji poporodowej jest psychoedukacja kobiet oraz ich rodzin. Należy również uczulić na ten problem tych pracowników służby zdrowia, którzy mają najczęstszy kontakt z matkami po porodzie: położne środowiskowe, ginekologów, pediatrów.

Słowa kluczowe: depresja poporodowa, depresja okołoporodowa

\section{Background}

Based on the systematic review of studies by Gavin et al. [1], postpartum depression (PPD) occurs in $7 \%$ of women within 3 months after childbirth; after taking into consideration minor depressive episodes, the percentage increases to $19.2 \%$. The most recent studies demonstrate that the incidence of PPD varies depending on the country, from $0.1 \%$ in Finland to $26.3 \%$ in India [2].

According to the ICD-10 classification criteria, PPD is a depressive episode with an onset within 6 weeks after childbirth [3]. In the DSM-IV classification, PPD is defined as a major depressive episode with an onset within 4 weeks after childbirth [4]. The authors of the DSM-5 classification abandoned the term "postpartum mood disorders" and replaced it with "peripartum", claiming that a considerable proportion of postpartum mood disorders have their onset in pregnancy [5]. The results of the available studies show, however, that postpartum depression can start 5 to 6 months after childbirth [6, 7, 8]. However, Sharma and Mazmanian [8] claim that introducing the parameter "with peripartum onset" was a mistake, as depressive disorders starting 
before and after delivery may differ in aetiology, symptom profile, and reaction to treatment.

The purpose of this study is to present a case of postpartum depression with psychotic symptoms and complications taking the form of extended suicide attempt. Further discussion will include issues related to the differentiation, prevention and treatment of postpartum depression.

\section{Case study}

A 25-year-old woman was transferred to the Clinic of Psychiatry from the Provincial Hospital with a diagnosed episode of severe depression with psychotic symptoms and a condition after a suicide attempt. The patient's medical history shows that she was born on time, and her early psychomotor development was normal. She did not suffer from any serious diseases as a child. She was brought up in a full family, with two siblings. Her family home has always been free from any forms of violence, alcohol abuse or psychoactive substance abuse. She did not go to kindergarten and her grandmother took care of her during that time. The patient evaluated her childhood in a positive way. She had a stronger bond with her mother and described her as restrained in showing her emotions. In the preschool age the patient experienced separation anxiety as a result of being away from her mother. Her relationship with her father was more distant. She completed primary school and general secondary school within the required time. Her educational results were very good and she did not experience problems with adaptation. She did not cause any major educational problems. She was surrounded by a close circle of trusted friends, avoided conflicts and was sensitive to criticism and rejection. When making decisions, she expected support from other people. Her parents often relieved her of her duties and considered her less resourceful than her older sister. After passing her secondary school final examinations she continued her education at a university. During that time she lived with her friend in a privately rented flat. She chose her field of studies herself. After graduation she returned to her family home and started a job as an office worker. She found her job rewarding and she quickly became apt at her professional duties. She was professionally active until her medical leave during pregnancy. She got married at the age of 24, after being engaged for five years. For a short time after marriage she lived with her husband in her family home, and later moved to a privately rented flat located nearby. The relationship between the couple was good and they had no financial problems. However, the patient's husband accused her of not being independent enough and complained about her reliance on her parents and the fact that she consulted each of her deci- sions with them. He claimed that she did not cut her mental umbilical cord. This was one of the reasons for their decision to move out from her parents' home. Two months after getting married the patient got pregnant. Her pregnancy was planned, and they both were happy about the prospect of having a baby. Almost from the beginning of her pregnancy the patient was on a medical leave due to the nature of her work. Throughout the pregnancy she regularly saw a gynaecologist for medical checkups, she underwent the required tests and fulfilled her doctor's recommendations. The first trimester passed without any complications. In the second trimester the patient was diagnosed with anaemia and was administered iron supplements, after which she complained of constipation. She experienced urinary tract infections and premature uterine contractions. The patient was afraid of preterm birth and the related complications for the child. In the 33rd week of pregnancy her attending doctor referred her to hospital with a suspicion of cholestasis of pregnancy. At the hospital it was decided that the patient needs to be hospitalised, which was surprising for her and intensified her anxiety about the child's health. In the 34 week of pregnancy an abnormal CTG reading made the doctors decide to carry out an urgent Caesarean section. Spinal anaesthesia was applied for the procedure. The patient had negative memories of the procedure: "I felt as the baby was wrenched away from me, they had problems with getting her out, it took a long time before the baby started crying (...), I was scared." After the childbirth she was hospitalised for 12 days at the Gynaecology and Obstetrics Ward. Due to difficulties with breathing the infant was placed in an incubator for 2 days and was fed through a tube. During her stay at the ward the patient was weepy, emotionally unsteady, insomniac, worried about her newborn's health and the impact that premature birth may have on her development.

After returning home the patient took care of the infant on her own. Her husband helped her in the evenings. Her mother and sister also offered help, but her husband insisted on her being able to deal with the child on her own. The infant suffered from baby colic. The infant was weepy, did not sleep much and had a weakly developed sucking impulse. The feeding process was additionally complicated by weekly developed nipples. The patient once visited a lactation consultant, but despite following her recommendations, problems with feeding sustained. After around 2 weeks after childbirth the patient's mental state deteriorated considerably. She had a low mood, was unable to enjoy her motherhood, was weepy and irritable. She claimed that she did not have a sufficiently strong maternal instinct and she blamed herself for it. She was constantly tired and did not sleep enough, even at times when she had a chance. Due to the low appetite she lost a 
considerable amount of weight, which was noticeable for people around her. She experienced attention deficits. She did not enjoy visits of her family members and started to isolate herself. She had difficulties with the simplest everyday decisions. Her anxiety related to her newborn's state of health also intensified. Despite paediatrician's assurances that there were no reasons to worry, the patient claimed that her child was not gaining enough weight and developed less quickly than other infants. She compared her child with her friend's baby, she looked for information on the normal psychomotor development of infants on the Internet. She frequently saw a paediatrician because she was afraid that the infant's weak appetite and the colic may be caused by some serious, undiagnosed disease. Later she began to blame herself for the alleged poor state of her baby's health. According to her husband, she fulfilled her household duties conscientiously, while the patient herself claimed that it was difficult for her to motivate herself to complete them; she did them mechanically and without the sense of satisfaction. She felt guilty that she did not care properly for her child, home and her husband. The patient did not tell her family how she felt because she did not want to burden others with her problems, and she was afraid that her husband would begin to "be sorry that he married her". Members of her closest family associated her condition with exhaustion related to caring for her newborn. Two months after childbirth she asked for a psychological consultation. She went with her husband, but she talked to the psychologist without his presence. Based on what the patient said, the psychologist stated that her mental state was a result of exhaustion and recommended a psychiatric consultation in case her state of health deteriorated further. Since then she had not seen a psychologist or psychiatrist, as she did not believe anyone could help her. Gradually she developed a delusion that her newborn did not love her because the baby did not smile at her and cried when she saw her. The patient thought that her presence was harmful to the child and that she did not deserve to be a mother. Gradually she began to prefer leaving the infant under the care of others. Two months after labour she began to have suicidal ideation without a specific plan: "it would be better for everyone if I died and my husband found another woman that would take a proper care for the baby." A month later she began to have infanticidal thoughts with an altruistic motivation: "I wanted for both of us to stop hurting." The suicidal and infanticidal thoughts began to intensify and were experienced by the patient as a crowding of thoughts. Four months after delivery, when the patient's husband went out to work, she drowned the infant and then tried to commit a suicide by jumping from a height. She had never prepared a specific suicide plan. As she later claimed, that day she was "like a machine, in a frenzy." Furthermore, some of the events of that day were lost to amnesia. She was hospitalised for two weeks at the Anaesthesiology and Intensive Therapy Ward. When the patient was admitted to the hospital, she was conscious and informed the doctor that her child had stayed in the house. Due to trauma-related pain, for a few days the patient was in a pharmacological coma. Her diagnosis included a post-traumatic shock, traumatic pneumothorax and hematoma, bilateral fraction of the pubic bone, iliac bone fracture, comminuted fracture of the sacral bone and a liver injury. After being woken up from the pharmacological coma the patient saw a psychiatrist, who ordered hospital treatment at the psychiatric ward as an absolute indication.

Later the patient was hospitalised at the psychiatric ward. During the stay at the ward she was in a profoundly low mood, with a psychomotor impairment, and was reluctant to talk about how she felt. She admitted to having suicidal thoughts. The results of the WISKAD test pointed to a low self-esteem, apathy, low mood and reduced activity, compulsive thinking combined with persistent anxiety and problems with concentration. Pharmacological treatment was applied: venlafaxine $225 \mathrm{mg} / \mathrm{d}$, mianserin $50 \mathrm{mg} / \mathrm{d}$, olanzapine $20 \mathrm{mg} / \mathrm{d}$, quetiapin 100 $\mathrm{mg} / \mathrm{d}$. Due to an insignificant improvement of her mental state and persistent suicidal thoughts she was transferred to the Psychiatry Clinic with diagnosed severe depression with psychotic symptoms for the continuation of her treatment. On the date of admission to the Clinic she had a complete auto- and allopsychic orientation and was verbally responsive. Her thinking and speech were slowed down. She reported the state of depressive disengagement (depresio sine depresione), being unable to experience joy or sadness as a result of suffering and guilt. She complained of free-floating anxiety, heart pounding, constipation, sleep pattern disorders (prolonged latency, fragmentation) and attention deficits. The patient denied having hallucinations of any modality. She showed some insight into pathological delusional judgments. She began to feel a growing sense of guilt and awaited punishment for the act that she committed. The patient confirmed having persistent suicidal ideation without a specific plan. She moved using a walker.

It was established that before childbirth the patient had not been to a psychiatrist or psychologist. In her family nobody has undergone any psychiatric treatment; her cousin committed a suicide, but little is known about his mental health. On the basis of the medical history the occurrence of affective disorders in the past was ruled out. The results of the Mood Disorder Questionnaire also excluded the bipolar spectrum. She rarely drunk alcohol and never used psychoactive substances. 
The results of laboratory tests: blood count, electrolytes, liver function tests, urinalysis, thyroid hormones and anti-TPO antibodies were normal. CT with contrast did not show any pathology in the central nervous system.

During the patient's stay at the Clinic her pharmacotherapy was modified by increasing the dose of venlafaxine to $300 \mathrm{mg} / \mathrm{d}$. Due to the high intensity of suicidal thoughts, a decision was made to apply electroconvulsive therapy (14 sessions). Patient was also covered with supportive individual psychotherapy. Attempts were also made to strengthen family support. An improvement was observed in the patient's mood and psychomotor drive, concentration and sleep pattern. Her feelings were released, and the anxiety level decreased significantly. She still experienced suicidal thoughts, but their intensity reduced to a great extent. Twice during the hospitalisation she was released for a few days' passes under the care of her husband. Her feelings were dominated by the sense of guilt for the committed infanticide. She thought that she did not deserve the support she was receiving from her family and the medical personnel. She was afraid of returning to her community. Furthermore, in contact with stimuli associated with maternity her mood deteriorated considerably.

The patient was released home with a recommendation of continued outpatient pharmacological treatment. Currently she is participating in individual psychotherapy. She was also recommended marriage counselling. Her suffering is of a unique nature. The symptoms of postpartum depression were represented by depressive mourning, additionally complicated by the fact that she herself caused the death of the mourned child.

\section{Discussion}

Postpartum depression (PPD) should be distinguished from other postpartum mood disorders, such as baby blues (maternal blues) and postpartum psychosis. Baby blues happens to $50 \%-85 \%$ of women in puerperium. It is a temporary condition which does not require pharmacotherapy and subsides spontaneously, usually by the 10th day after delivery. It is characterised with low mood and lability, weepiness, irritation, and sleep and appetite disorders. However, it is estimated that in approx. $20 \%$ of cases baby blues is a precondition of PPD and is associated with a 4-fold higher risk of PPD, therefore it is recommended to monitor the mental state of women with baby blues $[9,10]$. Postpartum psychosis occurs much less often, i.e. in $0.1 \%-0.2 \%$ of women. In most cases its symptoms develop up to one month after delivery, usually as early as on the third day. It is a sudden, acute condition with nonhomogenous psychopathological manifestations, with disorganised thinking and behaviour, mood disorders, positive symptoms and qualitative consciousness disorders, which can take a form similar to a delirium. Postpartum psychosis poses a serious threat to the life of mothers and their children due to intensified suicidal and infanticidal ideation and absolutely requires hospitalisation and pharmacotherapy $[10,11]$. It can be suspected that in the early postpartum period the analysed patient experienced baby blues symptoms such as affective lability, weepiness and sleep disorders. However, they did not subside spontaneously, but intensified with each day, turning into an episode of severe depression. Her delusions were consistent with her mood. No hallucinations or pseudohallucinations of any modality were identified. The course of the disease was not as acute and nonhomogeneous in terms of symptomatology as in the case of postpartum psychosis.

Postpartum depression may also constitute one of the episodes of unipolar depressive disorder (UDD) or bipolar affective disorder (BAD). The differentiation of these conditions is of key significance for the choice of pharmacotherapy and prevention. Akiskal [12] considered postpartum depression one of bipolar markers. Sharma and Khan [13] reported that up to $53 \%$ of women with postpartum depression in fact suffered from bipolar affective disorders. However, a study by Freeman et al. [14] episodes of mood disorders in puerperium were recorded in as many as $67 \%$ of women with a bipolar affective disorders, and in most cases these were depressive disorders. The risk of BAD in the postpartum period is approx. twice as high as UDD [15, 16]. Azorin et al. [17] inform, that depending on the adopted bipolarity criteria $15-50 \%$ of women with a major depression disorders in whom the first depressive episode occurred in puerperium in fact suffered from a bipolar disorder. In this group, in comparison to the groups in which the first depression episode was not related to childbirth, the following bipolar markers were found significantly more often: the incidence of a bipolar affective disorder among relatives of the first degree, a younger age at the onset of the disease ( $<30$ years), shorter and more frequent depressive disorders in the medical history ( $<1$ month, $>4$ episodes), the seasonality of mood disorders, frequent atypical psychotic symptoms (hyperphagia, hypersomnia) or mixed characteristics in the current depressive episode, mood lability, irritability or manic/hypomaniac symptoms after taking antidepressants. For this reason it is recommended to carry out screening studies for BAD in women with postpartum depression [17]. The results of the Mood Disorder Questionnaire obtained by the patient (3 points - only 2 symptoms in the analysed period significantly impairing the patient's functioning) do not allow the diagnosis of bipolarity. The medical history did not show any affective episodes in the past. However, a patient should be under close observation to rule out BAD due to the fact that the 
disorder appeared at a young age, the characteristics of PPD included psychotic symptoms and the possibility that her mood disorders are hereditary.

A systematic review of longitudinal studies shows that in most cases postpartum depression is limited in time and subsides 3-6 months after delivery. However, $50 \%$ of respondents in population studies and $30 \%$ of women participating in clinical group studies meet the criteria for a major depressive disorder a year or two years after childbirth. Taking into consideration the intensity of depression symptoms and their changes over time, it turns out that a chronic course of postpartum depression can be equivalent to 1 . a chronic major depression episode, 2. a chronic minor depression episode, 3. Recu rrent major depression episodes without complete remission between them. The risk factors for chronic postpartum depression are: low level of social support and poorquality partnership, the occurrence of depressive disorders in the medical history, sexual abuse in the past, a high level of parental stress, poor-quality maternal care in the childhood, and also such personality variables as immature defence mechanisms, high expectations and self-criticism [18]. It seems that in the patient in question chronic depression symptoms can be expected due to mourning and the persistent sense of guilt for the act that she committed. Therefore, the authors of this study claim that, apart from pharmacotherapy, it is crucial to focus on activities supporting family life, improving the quality of the marital relationship and individual psychotherapy.

It should be borne in mind that some symptoms typical for a depressive disorder, such as attention deficits, loss of energy, fatigue, psychomotor impairment or agitation, occur in the puerperium in approx. $17 \%$ of healthy women. However, their intensity and frequency may be lower than in the case of PPD [19]. In postpartum depression sadness can be masked by such symptoms as anxiety [20, 21, 22, 23], emotional lability [23], attention deficits, difficulties with making simple decisions [22, 283], psychomotor restlessness [22] and irritability [20, 23]. Pitt [23] claims that PPD is "atypical" and differs in terms of symptoms from depression occurring in other periods of life, i.e. it is characterised with a higher level of neuroticism. Dalton [24] mentions the following five most common PPD symptoms: anxiety, insomnia, agitation, irritability and attention deficits, while depression is mentioned as the 10 th most frequent symptom. Despite the fact that suicide attempts and suicides are much less frequent during pregnancy and puerperium than in the total population of women, suicide is the cause of $20 \%$ of deaths in the postpartum period. Self-harm ideation occurs in 5$14 \%$ of women in puerperium. The risk of suicidal death is significantly higher in women with postpartum depression and constitutes the second most frequent cause of death in this group [25]. In the study by Howard et al. [26], 9\% of women in the 6 th week after labour confirmed having suicidal thoughts, while in $4 \%$ of them such thoughts occurred often or sometimes. A higher intensity of suicidal ideation was associated with a higher score in the Edinburgh Postnatal Depression Scale. Among women with postpartum mental disorders unnatural cause of death represent $40 \%$ of fatalities in the first year after diagnosis. The risk of suicide in this period is almost 290 times higher than in the case of healthy women [27]. As the estimates show, $60 \%$ of women with postpartum depression may experience persistent thoughts, impulses and ideation of aggression towards their children. Such ideation, in the case of nonpsychotic depression, due to their ego-dystonic nature and the accompanying sense of guilt, is not turned into action, but sometimes may result in avoiding contact with the child $[28,29,30]$. The risk of infanticide may be much higher for depression with psychotic symptoms or in the presence of risky behaviour neglect or improper child care. Barr and Beck [30] claim that in women with PPD the thoughts of hurting or killing the infant may also result from a deformed sense of responsibility for the child - a mother, feeling that she does not have any choice, is planning to commit a suicide and decides to take her child with her in order not to leave him or her without care, even if she considers the care she provides inadequate. The authors of the aforementioned study emphasise that women with PPD conceal such thoughts from others, and if they consult a doctor, they are more likely to admit having suicidal than infanticidal thoughts and think that this way they will receive adequate treatment. Therefore, in every case of postpartum depression, especially with suicidal ideation, thoughts of hurting the infant should be taken into consideration and the doctor should actively ask questions on this issue. It seems that in the case in question the motive of the infanticide was altruistic and associated with a pathologically deformed sense of responsibility for the newborn.

Based on the analysis of PPD predictors, screening instruments are developed to assess the risk of postpartum depression during pregnancy. These include the PPDI-R (Postpartum Depression Predictor Inventory - Revised) [31], the BPDI (Brisbane Postnatal Depression Index) [32], and in Poland the Postpartum Mental Disorders Risk Questionnaire by KrzyżanowskaZbucka [30]. Table 1 based on the systematic review of studied by Norhayati et al. [2] presents the most frequent postpartum depression risk factors most often mentioned in literature. 
Table 1. Risk factors of postpartum depression

\begin{tabular}{|c|c|}
\hline Biological & $\begin{array}{l}\text { - physical health problems experienced by the } \\
\text { mother } \\
\text { - mother's BMI below } 20 \mathrm{~kg} / \mathrm{m}^{2}\end{array}$ \\
\hline Psychological & $\begin{array}{l}\text { - depressive disorders during pregnancy } \\
\text { - anxiety disorders during pregnancy } \\
\text { - mental disease in the medical history } \\
\text { - premenstrual dysphoric disorders in the } \\
\text { medical history } \\
\text { - poor-quality marital relationship } \\
\text { - high level of stress related to childcare } \\
\text { - stressful events during pregnancy or } \\
\text { puerperium } \\
\text { - negative attitude towards pregnancy } \\
\text { - experiencing mental, physical or sexual } \\
\text { abuse by the mother }\end{array}$ \\
\hline $\begin{array}{l}\text { Obstetrical and } \\
\text { infant-related }\end{array}$ & $\begin{array}{l}\text { - unplanned or unwanted pregnancy } \\
\text { - Caesarean section } \\
\text { - high level of labour pain } \\
\text { - disease diagnosed in the infant } \\
\text { - premature birth } \\
\text { - infant's difficult temper } \\
\text { - loss of the previous child } \\
\text { - inability to breastfeed or difficulties related } \\
\text { to it }\end{array}$ \\
\hline Socio-economic & $\begin{array}{l}\text { - young age of the mother (below 25) } \\
\text { - low level of the mother's education } \\
\text { - low income } \\
\text { - unemployment } \\
\text { - deficits in social support } \\
\text { - immigration }\end{array}$ \\
\hline
\end{tabular}

The strongest predictors of postpartum depression are depressive and anxiety disorders during pregnancy and previous episodes of postpartum depression and depression unrelated to pregnancy and childbirth [2]. In the study by Kettunen et al. [34], depression during pregnancy was associated with a 15-fold higher risk of PPD, while a history of PPD or depression unrelated to pregnancy or puerperium increased the risk 6 times. Women who experience a high level of antenatal anxiety are subject to a 2.6-3.8-fold higher risk of postpartum depression [35, 36]. It is worth pointing out that the studied patient was subject to a number of factors predisposing for postpartum depression. These included obstetrical risk factors, such as premature birth through Caesarean section and factors related to childcare: problems with breastfeeding, difficult temper of the infant and baby colic. Furthermore, the level of anxiety in the second and third trimester of pregnancy was high. The anxiety experienced in this period by the patient was related to her pregnancy, i.e. the possible negative consequence for the child's health in the event of premature birth. This type of anxiety is called antenatalrelated anxiety, and is related to pregnancy, labour, child's health or maternity [37]. It seems that one of the predisposing factors of the patient's depression which adds a specific tone to it is related to her personality traits such as a tendency to turn to others for support in everyday decisions, avoiding conflicts with people important for her in fear of losing their psychological support, and the sense of helplessness in lack of support. The above mentioned traits are characteristic of a dependent personality. The results of the available studies point to considerably more frequent personality disorders in women with PPD in comparison to the reference group [38, 39]. In the study on the overall population the criteria for at least one personality disorder were met by $50 \%$ (control group $0 \%$ ) of women with postpartum depression and these were most frequently cluster C disorders (dependent, avoidant and anankastic personality) [38]. In the clinical group, Apter et al. [39] recorded a twice as high frequency of personality disorders in women with PPD in comparison to the control group (60\% vs. 30\%); these were most often cluster B disorders (antisocial, narcissistic, histrionic, borderline). The major pathology in personality disorders lies in inflexible or inappropriate patterns of interpersonal relations, ways of self-perception and self-reflection and other patterns related to emotionality and impulse control. Childbirth can be a factor which exceeds the adaptation abilities of women with personality disorders. On the other hand, a defective personality may add some specific tone to the postpartum depression. It seems to be the case for the described patient.

Women with postpartum depression rarely seek professional assistance. In the study by Fronseca et. al. [40], only $13.6 \%$ of women with PPD confirmed that they saw a doctor to start proper treatment. This phenomenon may be related to the low level of education of young mothers on the symptomatology of postpartum mood disorders. They associate their emotional state with fatigue accompanying the toils of motherhood and with disillusionment resulting from the confrontation of the myth of motherhood with reality. Further barriers preventing early treatment are shame, attempts to avoid stigmatisation as a mentally ill person or even fear of being deprived of the right to care for the child in the event of diagnosing mental problems. Furthermore, people in the nearest environment may be unable to notice the problem for a long time due to their lack of knowledge on posptartum depression and due to associating its symptoms with childcare-related fatigue. On the other hand, women may choose not to share their difficulties with their families as they do not want to burden them with their problems or are afraid that the family might consider them inadequate as mothers. The level of knowledge on postpartum depression among healthcare professionals not dealing with psychiatry also seems insufficient [41, 42, 43]. It should also be kept in mind that women diagnosed with postpar- 
tum depression are reluctant to start treatment. In the study by Horowitz et al. [44], only $12 \%$ of women who were diagnosed with PPD between the 2 nd and 4 th week after labour participated in psychotherapy 2 months later, and the percentage of those taking antidepressants was even lower. The willingness to cooperate during treatment in this group of patients might also be unsatisfactory. It turns out that especially breastfeeding women often skip drug doses, take them arbitrarily or not at all [40]. Furthermore, the postpartum depression treatment results seem to be less satisfactory than major depression episodes unrelated to childbirth, which translates into a longer treatment period needed for remission and the necessity to introduce more changes in pharmacotherapy [45]. In the described case the decision to postpone psychiatric consultation until further deterioration of the patient's mental state was a mistake. The intensifying symptoms of the disease, anergy and depressive judgments of the future considerably lowered the chances for the patient's contacting a specialist again. Furthermore, the treatment and diagnosis process should have included the patient's husband, of course following her consent. The psychological education of family members on the nature of PPD seems to be the key element, as it changes the perspective of symptoms and makes it possible to provide the young mother with adequate support.

The systematic study reviews show that the effectiveness of psychotherapy and serotonin reuptake inhibitors (SRI) in the treatment of PPD is comparable [46, 47]. SRI pharmacotherapy seems to be slightly more effective than psychotherapy in the acute treatment phase, i.e. between the 6 th and 12 th week, with the advantage no longer present within the next 12 weeks of observation [46]. In addition, it has not been confirmed that adding SSRI to the therapy significantly improved its effectiveness [46, 47]. However, it should be emphasised that in most studies comparing the effectiveness of various forms of PPD treatment included only the cases of a mild or moderate intensity. The advantage of SRI over placebo rises significantly in severe depression, where the resulting HDRS score is at least 25 points. Sharma and Sommerdyk [48] claim that a slight advantage of SRI over placebo in postpartum depression can also be a result of: 1 . high anxiety level or frequent coexistence of anxiety disorders, 2. taking subtherapeutical drug doses, 3. a low level of cooperation during treatment, 3. undiagnosed bipolarity. 4. the presence of mixed depressive disorders, 5. a low oestrogen level in the postpartum period. SSRI might be more effective in women who meet the narrow criteria for unipolar postpartum depression with an onset after delivery. The authors of the aforementioned studies recommend reliance on the patient's preferences in the choice of the form of therapy for mild or moderate postpartum depression. However, severe postpartum depression episodes should be treated pharmacologically on the basis of algorithms developed for severe depression episodes unrelated to childbirth.

\section{Conclusions}

Psychoeducation of women during pregnancy, including their families, seems to be an extremely crucial element of postpartum depression prevention. It is also necessary to expand social awareness of postpartum mood disorders and to raise awareness among healthcare professionals who have frequent contact with young mothers after childbirth, i.e. community midwives, gynaecologists and paediatricians. According to the authors of the study, a perfect opportunity for a screening assessment of the mental state of women in puerperium with Edinburgh Postpartum Depression Scale are patronage visits of community midwives, who visit young mothers as many as four times within 6 weeks. These are home visits, in conditions in which mothers can feel comfortable and safe, and their duration is not authoritatively limited. In a longer time perspective, paediatricians could be obliged to carry out such screening during vaccination appointments between the 3rd and 4th, and 5th and 6th, month after delivery.

w okresie 6 tygodni po porodzie [3]. W klasyfikacji DSM-IV PPD definiowano jako epizod dużej depresji w początkiem w okresie 4 tygodni po porodzie.[4]. Autorzy klasyfikacji DSM-5 zrezygnowali z terminu „poporodowych” zaburzeń nastroju zastępując go terminem „okołoporodowe” argumentując, że znaczny odsetek poporodowych zaburzeń nastroju rozpoczyna się już w okresie ciąży [5]. Wyniki dostępnych badań informują jednak, że depresja poporodowa może rozpoczynać się $\mathrm{w}$ okresie 5 a nawet 6 miesięcy po porodzie $[6,7,8]$. Natomiast Sharma 
i Mazmanian [8] uważają, że wprowadzenie w klasyfikacji DSM-5 specyfikatora „z początkiem okołoporodowym” było błędem, ponieważ epizody depresyjne rozpoczynające się przed i po porodzie mogą mieć odmienną etiologię, profil objawów jak również inną odpowiedź na leczenie.

Celem pracy jest przedstawienie przypadku depresji poporodowej z objawami psychotycznymi, powikłanego próbą dokonania samobójstwa rozszerzonego. Następnie zostaną omówione zagadnienia związane $\mathrm{z}$ różnicowaniem, profilaktyką oraz leczeniem depresji poporodowej.

\section{Opis przypadku}

25-letnia kobieta została przeniesiona do kliniki psychiatrii ze szpitala wojewódzkiego z rozpoznaniem epizodu depresji ciężkiej z objawami psychotycznymi i stanu po próbie samobójczej. Z wywiadu wynika, że urodziła się o czasie, jej wczesny rozwój psychomotoryczny przebiegał prawidłowo. Jako dziecko poważnie nie chorowała. Była wychowywana w pełnej rodzinie. Ma dwójkę rodzeństwa. $W$ jej domu rodzinnym nigdy nie stosowano żadnej z form przemocy oraz nie nadużywano alkoholu ani substancji psychoaktywnych. Do przedszkola nie uczęszczała, w tym okresie opiekowała się nią babcia. Dzieciństwo ocenia pozytywnie. Silniej była związana z matką, którą określa jako nadopiekuńczą i powściągliwą w okazywaniu emocji. W wieku przedszkolnym występował u niej lęk separacyjny w reakcji na rozstanie z matką. Relacje z ojcem były chłodniejsze. Szkołę podstawową i liceum ogólnokształcące ukończyła o czasie. Uczyła się bardzo dobrze, nie miała problemów adaptacyjnych. Nie sprawiała większych problemów wychowawczych. Miała wąskie grono zaufanych znajomych, unikała konfliktów, była wrażliwa na krytykę i odrzucenie. Oczekiwała wsparcia innych osób w podejmowaniu decyzji. Często rodzice wyręczali ją z obowiązków i oceniali jako mniej „zaradną życiowo” niż starsza siostra. Po zdaniu matury kontynuowała naukę na uczelni wyższej. Mieszkała w tym okresie na stancji wraz z przyjaciółką. Studia były jej własnym wyborem. Po ukończeniu studiów powróciła do domu rodzinnego i rozpoczęła pracę $\mathrm{w}$ charakterze pracownika biurowego. Praca była dla niej satysfakcjonująca, szybko opanowała zakres swoich obowiązków. Była aktywna zawodowo aż do czasu przejścia na zwolnienie lekarskie w okresie ciąży. Związek małżeński zawarła w wieku 24 lat, po pięciu latach narzeczeństwa. Przez krótki okres po ślubie wraz z mężem mieszkała w swoim rodzinnym domu, następnie przeprowadziła się na stancję w bliskim sąsiedztwie. Relacje między małżonkami były dobre, nie mieli problemów finansowych. Jednak mąż zarzucał pacjentce, że jest mało samodzielna, pozwala wyręczać się rodzicom i konsultuje z nimi wszelkie decyzje. Uważał, że ma „nieodciętą pępowinę”. Było to jednym z powodów podjęcia decyzji o przeprowadzce. Dwa mie- siące po ślubie zaszła w ciążę. Ciąża była planowana. Obydwoje z mężem przyjęli ten fakt z radością. Niemal od początku ciąży pacjentka przebywała na zwolnieniu lekarskim z uwagi na charakter wykonywanej pracy. Przez całą ciążę regularnie zgłaszała się na wizyty kontrolne u ginekologa, wykonywała wszystkie zalecane badania i realizowała zalecenia lekarskie. Pierwszy trymestr ciąży przebiegał bez komplikacji. W drugim trymestrze zdiagnozowano u niej niedokrwistość i zlecono przyjmowanie preparatów żelaza, po których pojawiły się zaparcia. Występowały infekcje dróg moczowych oraz przedwczesne skurcze macicy. Pacjentka obawiała się przedwczesnego porodu i związanych z nim powikłań u dziecka. W 33 tygodniu ciąży lekarz prowadzący ciążę skierował ją do szpitala z podejrzeniem cholestazy ciążowej. W szpitalu uznano, że hospitalizacja jest konieczna, co było dla pacjentki zaskoczeniem i spotęgowało lęk o stan zdrowia dziecka. W 34 tygodniu ciąży z powodu nieprawidłowego zapisu KTG podjęto decyzję o wykonaniu pilnego cięcia cesarskiego. Zabieg został przeprowadzony w znieczuleniu podpajęczynówkowym. Poród pacjentka wspomina negatywnie „czułam jak wyszarpują mi dziecko, było zaplątane w pępowinę, nie mogli go wyciągnąć, długo nie płakało (...) bałam się". Po porodzie była hospitalizowana przez 12 dni w oddziale ginekologiczno-położniczym. Dziecko z powodu trudności z oddychaniem przez 2 dni przebywało $\mathrm{w}$ inkubatorze oraz było odżywiane przez sondę. W okresie pobytu na oddziale pacjentka była płaczliwa, chwiejna emocjonalnie, bezsenna, obawiała się o stan zdrowia dziecka oraz o to jak przedwczesny poród wpłynie na jego dalszy rozwój.

Po powrocie do domu opiekowała się dzieckiem samodzielnie. Mąż pomagał jej wieczorami. Pomoc oferowały również jej matka i siostra, jednak mąż nalegał by pacjentka starała się radzić sobie z dzieckiem samodzielnie. U dziecka wystąpiła kolka niemowlęca. Było płaczliwe, mało spało, miało słabo wykształcony odruch ssania. Proces karmienia komplikowały dodatkowo słabo wykształcone brodawki sutkowe. Pacjentka jednokrotnie korzystała z porady konsultantki laktacyjnej. Pomimo stosowania się do otrzymanych zaleceń problemy z karmieniem utrzymywały się. Po około 2 tygodniach od porodu stan psychiczny pacjentki znacznie się pogorszył. Jej nastrój był obniżony, nie potrafiła się cieszyć z macierzyństwa, była płaczliwa, drażliwa. Uważała, że nie ma wystarczająco silnie wykształconego instynktu macierzyńskiego i obwiniała się za to. Była stale zmęczona, mało spała, nawet wtedy, gdy miała taką możliwość. $\mathrm{Z}$ powodu spadku apetytu znacznie straciła na wadze, co było widoczne również dla otoczenia. Wystąpiły zaburzenia koncentracji uwagi. Nie cieszyły ją odwiedziny rodziny, zaczęła się izolować. Miała trudności w podejmowaniu najprostszych codziennych decyzji. Nasilił się również lęk 
o stan zdrowia dziecka. Mimo zapewnień lekarza pediatry o braku powodów do niepokoju uważała, że dziecko słabo przybiera na wadze i rozwija się gorzej niż jego rówieśnicy. Porównywała je z dzieckiem koleżanki, poszukiwała informacji $\mathrm{w}$ internecie na temat prawidłowego rozwoju psychofizycznego niemowląt. Wielokrotnie odwiedzała pediatrę, ponieważ obawiała się, że słaby apetyt dziecka, kolki, mogą być spowodowane jakąś poważną dotychczas nie rozpoznaną chorobą. Następnie zaczęła obwiniać siebie za zły w jej mniemaniu, stan zdrowia dziecka. Według informacji uzyskanych od męża obowiązki domowe wypełniała bardzo skrupulatnie. Od pacjentki otrzymaliśmy informację, że trudno jej było zmobilizować się do pracy w domu, obowiązki wykonywała mechanicznie, bez poczucia satysfakcji. Towarzyszyło temu poczucie winy, że źle zajmuje się dzieckiem, domem i mężem. Pacjentka nie informowała o swoim samopoczuciu rodziny ponieważ nie chciała obciążać innych swoimi problemami i obawiała się, że mąż zacznie „żałować, że się z nią ożenił". Najbliżsi członkowie rodziny jej stan psychiczny tłumaczyli przemęczeniem wynikającym z opieki nad dzieckiem. Dwa miesiące po porodzie poprosiła o wizytę $\mathrm{u}$ psychologa. Na konsultację pojechała $\mathrm{z}$ mężem, jednak rozmowę z psychologiem przeprowadziła bez jego obecności. Według informacji uzyskanych od pacjentki psycholog uznał, że jej stan psychiczny wynika ze zmęczenia i polecił konsultację u psychiatry w sytuacji, gdyby jej stan zdrowia w dalszym ciągu się pogarszał. Od tamtego czasu nie zgłosiła się więcej do psychologa ani do psychiatry. Uważała, że nikt nie jest w stanie jej pomóc. Stopniowo nabierała urojeniowego przekonania, że dziecko jej nie kocha, ponieważ się do niej nie uśmiecha, płacze na jej widok. Uważała, że jej bliskość jest dla dziecka krzywdząca i nie zasługuje na to, żeby być matką. Z czasem wolała, by to inni się opiekowali dzieckiem. Dwa miesiące po porodzie pojawiły się myśli samobójcze bez konkretnego planu realizacji „lepiej byłoby dla wszystkich gdybym umarła (...) żeby mąż znalazł sobie inną kobietę, która dobrze zaopiekowałaby się dzieckiem”. Miesiąc później pojawiły się myśli dzieciobójcze motywowane altruistycznie „ chciałam żebyśmy obydwoje przestali cierpieć”. Myśli samobójcze i dzieciobójcze przybierały na sile i odczuwane były jako natłok myśli. Cztery miesiące po porodzie, po wyjściu męża do pracy, pacjentka utopiła dziecko, a następnie dokonała zamachu samobójczego przez skok z wysokości .Nigdy nie przygotowywała konkretnego planu samobójstwa. Twierdziła, że działa wówczas „jak automat, w amoku”. Ponadto znaczna część faktów w tego dnia pokryta jest niepamięcią. Przez dwa tygodnie była hospitalizowana w oddziale Anestezjologii i Intensywnej Terapii. Przy przyjęciu do szpitala była przytomna i poinformowała lekarza, że w domu zostało jej dziecko. Z powodu bólu pourazowego pacjentkę przez kilka dni utrzymywano w stanie śpiączki farmakologicznej. Rozpoznano u niej wstrząs pourazowy, urazową odmę oraz krwiak jamy opłucnowej, obustronne złamanie kości łonowej, złamanie kości biodrowej, wieloodłamowe złamanie kości krzyżowej oraz uraz wątroby. Po wybudzeniu ze śpiączki farmakologicznej była konsultowana przez lekarza psychiatrę, który zalecił leczenie szpitalne w oddziale psychiatrii ze wskazań bezwzględnych.

Pacjentka była następnie hospitalizowana w oddziale psychiatrycznym. W trakcie hospitalizacji psychiatrycznej pacjentka była w nastroju głęboko obniżonym, spowolniała psychoruchowo, niechętnie rozmawiała o swoim samopoczuciu. Potwierdzała myśli samobójcze. Wyniki przeprowadzonego w oddziale badania WISKAD wskazywały na poczucie małej wartości, apatię, obniżony nastrój i aktywność, myślenie natrętne, uporczywie towarzyszący mu lęk, trudności z koncentracją uwagi. Zastosowano leczenie farmakologiczne: wenlafaksynę $225 \mathrm{mg} / \mathrm{d}$, mianserynę $50 \mathrm{mg} / \mathrm{d}$, olanzapinę $20 \mathrm{mg} / \mathrm{d}$, kwetiapinę $100 \mathrm{mg} / \mathrm{d}$. Z uwagi na nieznaczną poprawę stanu psychicznego i uporczywe myśli samobójcze została przeniesiona do kliniki psychiatrii z rozpoznaniem epizodu depresji ciężkiej z objawami psychotycznymi celem kontynuacji leczenia. W dniu przyjęcia do kliniki była w pełnej orientacji auto i allopsychicznej, w jasnej świadomości, w logicznym kontakcie werbalnym. Tok myślenia i wypowiedzi był zwolniony. Relacjonowała stan depresyjnego zobojętnienia (depresio sine depresione) z niezdolnością do przeżywania nie tylko radości, ale i smutku, będący źródłem cierpienia i poczucia winy. Skarżyła się na lęk wolnopłynący, kołatania serca, zaparcia, zaburzenia wzorca snu (wydłużona latencja, fragmentacja), zaburzenia koncentracji uwagi. Przeczyła omamom wszelkiej modalności. Wykazywała częściowy wgląd w chorobowe sądy urojeniowe. Odczuwała nasilone poczucie winy z oczekiwaniem kary za czyn, jakiego dokonała. Potwierdzała występowanie uporczywych myśli samobójczych bez konkretnego planu realizacji. Poruszała się przy pomocy chodzika.

Ustaliliśmy, że przed porodem pacjentka nie leczyła się psychiatrycznie i nie korzystała z porad psychologa. $\mathrm{W}$ jej rodzinie nikt nie leczył się psychiatrycznie, natomiast brat cioteczny popełnił samobójstwo. Niewiele było jednak wiadomo na temat jego stanu zdrowia psychicznego. Na podstawie zebranego wywiadu wykluczono występowanie epizodów afektywnych w przeszłości. Wyniki uzyskane w Kwestionariuszu Zaburzeń Nastroju również wykluczyły spektrum dwubiegunowości. Alkohol piła sporadycznie, nigdy nie używała substancji psychoaktywnych.

Wyniki badań laboratoryjnych: morfologia krwi, elektrolity, próby wątrobowe, analiza moczu, poziom hormonów tarczycowych oraz przeciwciał przeciwko peroksydazie tarczycowej były w zakresie normy. W badaniu tomografii komputerowej $\mathrm{z}$ kontrastem nie stwierdzono patologii ośrodkowego układu nerwowego. 
W trakcie pobytu pacjentki w Klinice zmodyfikowano farmakoterapię: zwiększono dawkę wenlafksyny do $300 \mathrm{mg} / \mathrm{d}$. Z uwagi na duże nasilenie myśli samobójczych zdecydowano się zastosować u pacjentki terapię elektrowstrząsową (14 zabiegów). Pani M. została również objęta indywidualną psychoterapią wspierającą. Podjęto także działania wzmacniające wsparcie rodzinne. Uzyskano poprawę w zakresie nastroju i napędu psychoruchowego, koncentracji uwagi, wzorca snu. Jej uczucia uległy odblokowaniu. Poziom lęku uległ istotnej redukcji. W dalszym ciągu utrzymywały się myśli samobójcze, jednak ich nasilenie było znacznie zredukowane. W okresie hospitalizacji pacjentka kilkukrotnie była zwalniana ze szpitala na kilkudniowe przepustki pod opieką męża. W jej przeżywaniu dominowało poczucie winy z powodu zabicia dziecka. Uważała, że nie zasługuje na wsparcie jakie otrzymywała od rodziny i personelu medycznego. Obawiała się powrotu do środowiska, w którym do tej pory funkcjonowała. Ponadto $\mathrm{w}$ kontakcie $\mathrm{z}$ bodźcami kojarzącymi się z macierzyństwem jej samopoczucie znacznie się pogarszało.

Pacjentka została wypisana do domu z zaleceniem kontynuowania leczenia farmakologicznego $\mathrm{w}$ warunkach ambulatoryjnych. Pacjentka aktualnie objęta jest psychoterapią indywidualną. Zalecono również terapię małżeńską. Jej cierpienie ma wymiar niezwykle indywidualny. Symptomy depresji poporodowej zostały wyparte przez depresyjną reakcję żałoby, którą komplikuje fakt, że to ona sama przyczyniła się do śmierci opłakiwanego dziecka.

\section{Omówienie}

Depresję poporodową (PPD) należy różnicować $\mathrm{z}$ innymi zaburzeniami nastroju okresu poporodowego takimi, jak smutek poporodowy (baby blues, maternal blues) lub psychoza poporodowa (postpartum psychosis). Smutek poporodowy dotyczy od $50 \%$ do $85 \%$ kobiet $\mathrm{w}$ okresie połogu. Jest przejściowym stanem nie wymagającym farmakoterapii, ustępującym samoistnie zwykle do 10 dnia po porodzie. Cechuje się obniżeniem i labilnością nastroju, płaczliwością, uczuciem poirytowania, zaburzeniami snu i apetytu. Ocenia się jednak, że w około $20 \%$ przypadków jest on zapowiedzią PPD i wiąże się $\mathrm{z}$ 4-krotnie wyższym ryzykiem tego zaburzenia. Zaleca się monitorowanie stanu psychicznego kobiet ze smutkiem poporodowym $[9,10]$.Psychoza poporodowa występuje znacznie rzadziej i dotyczy od $0,1 \%$ do $0,2 \%$ kobiet. W większości przypadków jej objawy rozwijają się w okresie miesiąca po porodzie, najczęściej już trzeciego dnia. Jest to stan nagły, o ostrym przebiegu i niehomogenicznym obrazie psychopatologicznym, z dezorganizacją myślenia i zachowania, zaburzeniami nastroju, objawami wytwórczymi a nawet jakościowymi zaburzeniami świadomości, przez co może przybierać formę podobną do stanu majaczeniowego. Psychoza poporodowa, z uwagi na myśli samobójcze i dzieciobójcze, stanowi poważne zagrożenie życia matek i ich dzieci oraz wymaga bezwzględnej hospitalizacji i farmakoterapii $[10,11]$. Można przypuszczać, że w bezpośrednim okresie poporodowym u opisywanej pacjentki wystąpiły objawy baby blues takie jak labilność afektywna, płaczliwość oraz zaburzenia snu. Nie ustąpiły jednak samoistnie, lecz z każdym dniem przybierały na sile osiągając ostatecznie obraz epizodu depresyjnego o ciężkim nasileniu. Wypowiadane treści urojeniowe były spójne z nastrojem. Przebieg choroby nie był tak gwałtowny i niehomogeniczny pod względem symptomatologii jak ma to miejsce w psychozie poporodowej.

Depresja poporodowa może również być jednym z epizodów choroby afektywnej jednobiegunowej (CHAJ) lub dwubiegunowej (CHAD). Różnicowanie tych stanów chorobowych ma kluczowe znaczenie dla sposobu farmakoterapii i profilaktyki. Akiskal [12] zaliczył depresję poporodową do markerów dwubiegunowości. Sharma i Khan [13] informują, że nawet 53\% kobiet z depresją poporodową $\mathrm{w}$ istocie choruje na zaburzenia afektywne dwubiegunowe. Natomiast w badaniu Freeman i wsp. [14] epizody zaburzeń nastroju w okresie poporodowym odnotowano aż u $67 \%$ kobiet z chorobą afektywną dwubiegunową i najczęściej były to epizody depresyjne. Ryzyko występowania zaburzeń nastroju w okresie poporodowym w CHAD jest około dwukrotnie większe niż w CHAJ [15,16]. Azorin i wsp.[17] informują, że w zależności od przyjętych kryteriów bipolarności, od 15-50\% kobiet z dużą depresją, u których pierwszy epizod depresji wystąpił w okresie poporodowym, choruje w istocie na zaburzenie afektywne dwubiegunowe. W tej grupie, w porównaniu do grupy, u których pierwszy epizod depresji nie miał związku z porodem, istotnie częściej stwierdzano markery dwubiegunowości takie jak: występowaniem choroby afektywnej dwubiegunowej u krewnych pierwszego stopnia, niższy wiek początku choroby (>30 lat), krótsze i częstsze epizody depresyjne w wywiadzie(>1 miesiąca, <4 epizody), sezonowość zaburzeń nastroju, częstsze występowanie objawów psychotycznych, atypowych ( hiperfagia, hipersomia) lub cech mieszanych w aktualnym epizodzie depresji, labilność nastroju, drażliwości, objawy maniakalne/ hipomaniakalne po lekach przeciwdepresyjnych. Z tego właśnie powodu rekomenduje się przeprowadzanie badań przesiewowych w kierunku CHAD u kobiet z depresją poporodową [17]. Wynik jaki uzyskała nasza pacjentka w Kwestionariuszu Zaburzeń Nastroju (3 punkty -jedynie 2 objawy w tym samym okresie znacznie zaburzające funkcjonowanie) nie uprawnia do rozpoznania u niej cech dwubiegunowości. Zebrany wywiad nie ujawnił także epizodów afektywnych w przeszłości. Pacjentka powinna jednak być czujnie obserwowano w kierunku CHAD z uwagi na młody wiek 
zachorowania, objawy psychotyczne w obrazie PDD oraz prawdopodobne obciążenie dziedziczne zaburzeniami nastroju.

Z systematycznego przeglądu badań longitudinalnych wynika, że w większości przypadków depresja poporodowa jest stanem ograniczonym czasowo i ustępuje w ciągu 3 do 6 miesięcy po porodzie. Jednak 50\% respondentek $\mathrm{w}$ badaniach populacyjnych oraz $30 \% \mathrm{w}$ badaniach dotyczących grup klinicznych spełnia kryteria dużego epizodu depresyjnego jeszcze rok a nawet dwa lata po narodzinach dziecka. Jeśli uwzględni się nasilenie objawów depresji i ich zmienność w czasie okazuje się, że przewlekły przebieg depresji poporodowej może być równoważny z 1 . przewlekłym epizodem dużej depresji, 2. przewlekłym epizodem małej depresji 3. nawracającymi epizodami dużej depresji bez pełnej remisji pomiędzy nimi. Czynnikami ryzyka przewlekłego przebiegu depresji poporodowej są: niski poziom wsparcia społecznego i jakości związku partnerskiego, występowanie zaburzeń depresyjnych $\mathrm{w}$ wywiadzie, doświadczenia wykorzystywania seksualnego, wysoki poziom stresu rodzicielskiego, niska jakość opieki ze strony matki w dzieciństwie oraz takie zmienne osobowościowe jak niedojrzałe mechanizmy obronne, wysoki poziom wymagań i autokrytycyzmu [18]. Wydaje się, że u opisywanej pacjentki możemy spodziewać się przewlekania objawów depresyjnych. Mogą być one podtrzymywane przez reakcję żałoby oraz niesłabnące poczucie winy z powodu czynu jakiego się dopuściła się pacjentka. Dlatego w naszym odczuciu poza farmakoterapią, niezwykle ważne są tu działania ukierunkowane na wzmacnianie wsparcia rodzinnego, poprawę jakość relacji w diadzie małżeńskiej oraz psychoterapia indywidualna.

Należy mieć na uwadze, że części objawów typowych dla epizodu depresyjnego takich jak zaburzenia koncentracji uwagi, spadek energii, poczucie zmęczenia, spowolnienie lub pobudzenie psychoruchowe występuje w okresie poporodowym u około $17 \%$ zdrowych kobiet. Jednak ich nasilenie oraz częstość są mniejsze niż PPD [19]. W depresji poporodowej smutek może być przysłonięty przez takie objawy jak lęk [20,21,22,23], labilność emocjonalna [23], zaburzenia koncentracji uwagi ,trudności w zakresie podejmowania prostych decyzji [22,283], niepokój psychoruchowy [22] oraz drażliwość [20,23]. Pitt [23] uważa, że PPD charakteryzuje się pewną „atypowością” i różni się pod względem symptomatologii od depresji występującej w innych okresach życia wyższym poziomem neurotyczności. Dalton [24] wśród pięciu najczęściej występujących objawów PDD wymienia lęk, bezsenność, agitację, drażliwość oraz zaburzenia koncentracji uwagi, natomiast depresja znajduje się dopiero na 10 miejscu. Chociaż próby samobójcze oraz samobójstwa dokonane zdarzają się znacznie rzadziej w okresie ciąży i po porodzie niż w populacji ogólnej kobiet, to samobójstwo jest przyczyną 20\% zgonów w okresie poporodowym. Myśli dotyczące dokonania samouszkodzeń występują u 5\% do $14 \%$ kobiet w okresie poporodowym. Ryzyko samobójczej śmierci jest natomiast istotnie większe u kobiet $\mathrm{z}$ depresją poporodową i stanowi drugą przyczyną śmierci $\mathrm{w}$ tej grupie [25]. W badaniu Howard i wsp.[26] $9 \%$ kobiet w 6 tygodniu po porodzie potwierdzało występowanie myśli samobójczych, natomiast u $4 \%$ występowały one często lub czasami. Większe nasilenie myśli samobójczych wiązało z wyższą punktacją w Edynburskiej Skali Depresji Poporodowej. U kobiet z poporodowymi zaburzeniami psychicznymi $40 \%$ zgonów w okresie pierwszego roku po postawieniu diagnozy ma przyczynę nienaturalną. Ryzyko samobójstwa w tym okresie jest niemal 290 razy większy niż u zdrowych kobiet [27]. Szacuje się, że aż 60\% kobiet z depresją poporodową może doświadczać natrętnych myśli, impulsów i wyobrażeń dotyczących agresji skierowanej do własnego dziecka. Tego typu zachowania w przypadku depresji niepsychotycznej, z uwagi na ich egodystoniczność i towarzyszące im poczucie winy, nie są realizowane, jednak z czasem mogą skutkować unikaniem kontaktu z dzieckiem [28,29,30]. Ryzyko zabicia dziecka może być znacznie większe w depresji z objawami psychotycznymi lub w przypadku występowania zachowań ryzykownych: zaniedbywania lub błędów w opiece nad dzieckiem. Barr i Beck [30] informują, że myśli dotyczące skrzywdzenia lub zabicia dziecka u kobiet z PPD mogą wynikać również ze zniekształconego chorobowo poczucia odpowiedzialności za dziecko, kiedy matka czując, że znajduje się w sytuacji bez wyjścia planuje samobójstwo i nie chcąc pozbawiać dziecka opieki, nawet nieadekwatnej w jej ocenie, decyduje się zabrać je ze sobą. Autorzy powyższego badania zaznaczają, że kobiety z PPD ukrywają tego typu myśli przed otoczeniem. Zgłaszając się do lekarza są bardziej skłonne do ujawniania myśli samobójczych niż dzieciobójczych licząc, że w ten sposób uzyskają adekwatne leczenie. Dlatego w każdym przypadku depresji poporodowej, szczególnie z myślami samobójczymi, należy brać pod uwagę i aktywnie dopytywać o myśli dotyczące skrzywdzenia dziecka. Wydaje się, że w opisanym przez nas przypadku, zabicie dziecka miało charakter altruistyczny, wiązało się z zniekształconym chorobowo poczuciem odpowiedzialności oraz urojeniomymi sądami depresyjnymi.

W oparciu o analizę predyktorów PPD tworzone są narzędzia skriningowe przeznaczone do oceny ryzyka wystąpienia depresji poporodowej już w okresie ciąży. Do tego typu metod zaliczamy kwestionariusz PPDI-R (Postpartum Depression Predictor Inventory-Revised) [31], BPDI (Brisbane Postnatal Depression Index) [32], w Polsce Kwestionariusz Ryzyka Zaburzeń Psychicznych po Porodzie autorstwa Krzyżanowskiej-Zbuckiej [33]. W Tabeli 1. sporządzonej na postawie systematycznego przeglądu badań autorstwa Norhayati i wsp [2]. przedstawiono najczęściej wymieniane w literaturze czynniki ryzyka depresji poporodowej. 
Tab.1. Czynniki ryzyka depresji poporodowej

\begin{tabular}{|l|l|}
\hline Biologiczne & $\begin{array}{l}\text { zły stan zdrowia fizycznego matki } \\
\text { BMI poniżej } 20 \mathrm{~kg} / \mathrm{m}^{2} \text { u matki }\end{array}$ \\
\hline Psychologiczne & -zaburzenia depresyjne w okresie ciąży \\
& $\begin{array}{l}\text {-zaburzenia lękowe w okresie ciąży } \\
\text {-choroba psychiczna w wywiadzie } \\
\text {-przedmiesiączkowe zaburzenia dysforyczne } \\
\text { w wywiadzie } \\
\text {-zła jakość relacji małżeńskiej } \\
\text {-wysoki poziom stresu związanego z opieką } \\
\text { nad dzieckiem } \\
\text {-stresujące wydarzenia okresie ciąży lub } \\
\text { połogu } \\
\text {-negatywny stosunek do ciąży } \\
\text {-doświadczenia przemocy psychicznej, } \\
\text { fizycznej i seksualnej u matki }\end{array}$ \\
\hline Położnicze & -nieplanowana lub niechciana ciąża \\
związane & -poród przez cięcie cesarskie \\
dzieckiem & -wysoki poziom bólu porodowego \\
-choroba u dziecka \\
-wcześniactwo \\
-trudny temperament dziecka \\
-utrata dziecka po poprzedniej ciąży \\
-brak lub niepowodzenia w karmieniu piersią
\end{tabular}

Najsilniejszymi predyktorami depresji poporodowej są zaburzenia depresyjne oraz lękowe w okresie ciąży oraz epizody depresji poporodowej jak i nie związanej z ciążą i porodem w przeszłości [2]. W badaniu Kettunen i wsp.[34] depresja w okresie ciąży wiązała się z 15-krotnie większym ryzykiem PPD, natomiast PPD $\mathrm{w}$ wywiadzie lub depresja nie związana z ciążą lub połogiem zwiększała to ryzyko 6-krotnie. Kobiety, które w czasie ciąży doświadczają wysokiego poziomu lęku obarczone są od 2,6 do 3,8 wyższym ryzykiem depresji poporodowej $[35,36]$. Łatwo zauważyć, że u opisywanej pacjentki wystąpił szereg czynników predysponujących do depresji poporodowej. Były to zarówno położnicze czynniki ryzyka takie jak: przedwczesny poród przez cięcie cesarskie jak również czynniki związane $\mathrm{z}$ opieką nad dzieckiem: trudności w karmieniu piersią, trudny temperament dziecka i kolka niemowlęca. Również poziom lęku w drugim i trzecim trymestru ciąży był wysoki. Lęk jakiego doświadczała w tym okresie pacjentka, miał związek z ciążą i dotyczył obaw o możliwe negatywne konsekwencje zdrowotne u dziecka w sytuacji przedwczesnego porodu. Tego typu lęk określa się jako lęk związany z ciążą (antenatal - related anxiety). Odzwierciedla on obawy o ciążę, poród, zdrowie dziecka oraz macierzyństwo [37]. Wydaje się, że jednym z czynników predysponujących jak i nadających pewnego rodzaju kolorytu depresji poporodowej u pacjentki były jej cechy osobowości, takie jak skłonność do poszukiwania wsparcia ze strony innych osób w podejmowaniu codziennych decyzji, unikanie konfliktów ze znaczącymi osobami z obawy przed utratą ich psychologicznego wsparcia, poczucia bezradności w sytuacji utraty wsparcia. Powyższe cechy osobowości charakterystyczne są dla osobowości zależnej. Wyniki dostępnych badań informują o istotnie częstszym występowaniu zaburzeń osobowości u kobiet z PPD, w porównaniu z grupą odniesienia [38.39]. W badaniu dotyczących populacji ogólnej kryteria co najmniej jednego zaburzenia osobowości spełniało 50\% (grupa kontrolna 0\%) kobiet $\mathrm{z}$ depresją poporodową i najczęściej były to zaburzenia osobowości klastra C (zależna, unikowa, anankastyczna)[38]. W grupie klinicznej Apter i wsp.[39] odnotowali natomiast dwukrotnie częstsze występowaniu zaburzeń osobowości u kobiet z PPD w porównaniu z grupą kontrolną (60\% vs.30\%) i najczęściej były to zaburzenia osobowości z klastra B (antyspołeczna, narcystyczna, histrioniczna, bordeline). Centralną patologią w zaburzeniach osobowości są sztywne, mało elastyczne, nieprawidłowe wzorce w zakresie relacji interpersonalnych, sposobu postrzegania i myślenia o sobie oraz innych jak również w zakresie uczuciowości i panowania nad impulsami. Narodziny dziecka mogą być czynnikiem, który przekracza możliwości adaptacyjne kobiet $\mathrm{z}$ zaburzeniami osobowości. Z drugiej strony nieprawidłowa osobowość może nadawać swoistego kolorytu depresji poporodowej. Wydaje się, że z taką właśnie sytuacją mieliśmy do czynienia w przypadku naszej pacjentki.

Kobiety chorujące na depresję poporodową rzadko z własnej woli poszukują pomocy u profesjonalistów. W badaniu Fronseca i wsp. [40] jedynie 13,6 \% kobiet z PPD potwierdzało, że zgłosiło się do lekarza w celu podjęcia adekwatnego leczenia. Zjawisko to może mieć związek z niskim poziomem edukacji młodych matek w zakresie symptomatologii poporodowych zaburzeń nastroju. Swój stan emocjonalny utożsamiają ze zmęczeniem towarzyszącym trudom macierzyństwa lub wiążą z rozczarowaniem wynikającym z konfrontacji mitu macierzyństwa z rzeczywistością. Kolejnymi barierami opóźniającymi leczenie są wstyd, chęć uniknięcia stygmatyzacji jako osoby chorej psychicznie a nawet lęk przed pozbawieniem możliwości opieki nad dzieckiem w sytuacji ujawnienia problemów psychicznych. Również najbliższe otocze,, z powodu braku wiedzy lub błędnej interpretacji objawów może długo nie dostrzegać problemu. $\mathrm{Z}$ drugiej strony kobiety mogą nie ujawniać swoich problemów rodzinie, ponieważ nie chcą jej dodatkowo obciążać 
lub obawiają się, że zostaną uznane jako nieadekwatne w roli matki. Poziom wiedzy na temat depresji poporodowej wśród pracowników służby zdrowia nie związanych z psychiatrią również wydaje się być niewystarczający $[41,42,43]$. Należy mieć na uwadze, że kobiety, u których postawiono już diagnozę depresji poporodowej niechętnie podejmują leczenie. W badaniu Horowitz i wsp.[44] jedynie $12 \%$ kobiet, u których między 2 i 4 tygodniem po porodzie zdiagnozowano PPD 2 miesiące później uczestniczyło w psychoterapii, a jeszcze mniejszy odsetek przyjmował leki przeciwdepresyjne. Również poziom współpracy w leczeniu w tej grupie pacjentek może nie być zadowalający. Okazuje się, że szczególnie kobiety karmiące piersią często celowo opuszczają dawki leków, stosują je ad hoc lub nie przyjmują ich w ogóle [40]. Dodatkowo wyniki leczenia depresji poporodowej wydają się być mniej zadowalające niż epizodów dużej depresji nie związanej z porodem, co przejawia się dłuższym okresem leczenia do osiągnięcia remisji oraz koniecznością dokonywania większej ilości zmian leków[45]. W opisywanym przez nas przypadku błędem było odroczenie konsultacji psychiatrycznej na wypadek dalszego pogorszenia stanu psychicznego. Narastająca symptomatologia choroby, anergia, depresyjne sądy dotyczące przyszłości znacznie redukowały prawdopodobieństwo, że pacjentka z własnej woli ponownie skontaktuje się ze specjalistą. Ponadto w procesie leczenia i diagnozy należało, oczywiście za zgodą pacjentki, włączyć jej męża. Psychoedukacja członków rodziny w zakresie natury PPD wydaje się być tu kluczowa, ponieważ zmienia perspektywę widzenia prezentowanych objawów oraz daje szansę na stworzenie adekwatnego wsparcia dla młodej matki.

Z systematycznych przeglądów badań wynika, że skuteczność psychoterapii oraz inhibitorów wychwytu zwrotnego serotoniny (SSRI) w leczeniu PPD jest porównywalna [46,47] Farmakoterapia SSRI wydaje się nieznacznie przewyższać skutecznością psychoterapię w ostrej fazie leczenia tj. między 6 i 12 tygodniem, po czym efekt ten zanika w okresie kolejnych 12 tygodni obserwacji [46]. Ponadto nie potwierdzono, by dołączenie SSRI do psychoterapii istotnie poprawiało jej wyniki $[46,47]$. Należy jednak zaznaczyć, że w większości badań dotyczących porównywania skuteczności różnych form leczenia PPD uwzględniano jedynie przypadki depresji o łagodnym lub umiarkowanym nasileniu. Przewaga SSRI nad placebo wyraźnie wzrasta w depresji o dużym nasileniu, gdzie wyjściowa punktacja w skali HDRS wynosi co najmniej 25 punkty. Sharma i Sommerdyk [48] uważają że, niewielka przewaga skuteczności SSRI nad placebo $\mathrm{w}$ depresji poporodowej może również wynikać z: 1. wysokiego nasilenia lęku lub częstego współwystępowania zaburzeń lękowych, 2. stosowania subterapeutycznych dawek leków, 3. niskiego poziomu współpracy w leczeniu,
4. nierozpoznanej dwubiegunowości, 5. występowania depresyjnych epizodów mieszanych 6. niskiego poziomu estrogenów w okresie poporodowym. SSRI mogą być bardziej skuteczne u kobiet, które spełniają wąskie kryteria depresji poporodowej jednobiegunowej z początkiem po porodzie. Autorzy wyżej cytowanych badań rekomendują, by w przypadku depresji poporodowej o lekkim i umiarkowanym nasileniu przy wyborze formy terapii kierować się preferencjami pacjentki. Natomiast epizody ciężkiej depresji poporodowej powinny być leczone farmakologicznie $\mathrm{w}$ oparciu o algorytmy opracowane dla leczenia ciężkich epizodów depresyjnych niezwiązanych z porodem.

\section{Wnioski}

Niezwykle ważnym elementem prewencji depresji poporodowej wydaje się być psychoedukacja kobiet oraz ich rodzin już w okresie ciąży. Należałoby również pogłębić świadomość społeczną w zakresie poporodowych zaburzeń nastroju oraz uczulić na ten problem tych pracowników służby zdrowia, którzy mają najczęstszy kontakt z młodymi matkami po porodzie a więc: położne środowiskowe, lekarzy ginekologów i pediatrów. Według nas idealną okazją do przeprowadzenia skriningowej oceny stanu psychicznego położnicy z wykorzystaniem Edynburskiej Skali Depresji Poporodowej są wizyty patronażowe położnych środowiskowych, które w okresie 6 tygodni po porodzie odwiedzają młode matki aż czterokrotnie. Wizyty te odbywają się w domu, a więc w komfortowych i bezpiecznych dla matki warunkach, a czas ich trwania nie jest odgórnie ograniczony. W dalszej perspektywie czasowej mogliby być do tego zobligowani lekarze pediatrzy przy okazji wizyt szczepiennych między 3 i 4 miesiącem oraz 5 i 6 miesiącem po porodzie.

\section{References:}

1. Gavin, N., I. Gaynes, B. N. Lohr, K. N. Meltzer-Brody, S. Gartlehner, G. Swinson, T. Perinatal depression: a systematic review of prevalence and incidence. Obstet Gynecol.2005; 106(5,1):1071-1083.

2. Norhayati M. N., Hazlina N. N. Asrenee, A. R. Emilin, W.W. Magnitude and risk factors for postpartum depression. A literature review. J Affect Disord. 2015;1(175): 34-52.

3. Pużyński S., Wciórka J. Klasyfikacja zaburzeń psychicznych i zaburzeń zachowania ICD-10. Opisy kliniczne i wskazówki diagnostyczne. Uniwersyteckie Wydawnictwo Medyczne Vesalius. Instytut Psychiatrii i Neurologii .Kraków-Warszawa:2000.

4. Wciórka J. Kryteria diagnostyczne według DSM-IV-TR. Elsevier Urban and Partner. Wrocław:2008.

5. Rybakowski J., Dudek J., Jaracz D., Choroby afektywne w: Standardy leczenia farmakologicznego niektórych zaburzeń psychicznych. red. Jarema M. Via Medica. Gadańsk:86-87:2015.

6. Munk-Olsen T., Laursen T. M., Pedersen C. B., Mors O., Mortensen, P. B. New parents and mental disorders: a population-based register study. JAMA. 2006;296(21):2582-2589.

7. Wisner K. ., Sit D. K., McShea M. C., Rizzo D. M., Zoretich R. A., Hughes C. L. Onset timing, thoughts of self-harm, and diagnoses in postpartum women with screen-positive depression findings. JAMA Psychiatry.2013;70(5):490-498. 
8. Sharma V., Mazmanian D. The DSM-5 peripartum specifier: prospects and pitfalls. Arch Womens Ment Health. 2014; 17(2):171-173.

9. .Reck C., Stehle E., Reinig K., Mundt C. Maternity blues as a predictor of DSM-IV depression and anxiety disorders in the first three months postpartum. J Affect Disord.2009; 113(1):77-87.

10. Bothan P. Postpartum mood disorders-a practitioner's guide to diagnosis and treatment. South African Journal of Psychiatry.2015; 9(1), 6-8

11. Spinelli M. G. Postpartum psychosis: detection of risk and management. Am J Psychiatry.2009;166(4):405-408.

12. Akiskal H. S., Walker P., Puzantian V. R., King D., Rosenthal T. L., Dranon M. Bipolar outcome in the course of depressive illness: phenomenologic, familial, and pharmacologic predictors. J Affect Disord.1983; 5(2): 115-128.

13. Sharma V., Khan M. (2010). Identification of bipolar disorder in women with postpartum depression. Bipolar Disord. 2010;12(3):335-340.

14. Freeman M. P., Smith K. W., Freeman S. A., McElroy S. L., Kmetz G. E., Wright R., Keck Jr. P. E.. The impact of reproductive events on the course of bipolar disorder in women.J Clin Psychiatry, 2002;63(4), 284-287.

15. Viguera A. C., Tondo L., Koukopoulos A. E., Reginaldi D., Lepri B., \& Baldessarini R. J. (2011). Episodes of mood disorders in 2,252 pregnancies and postpartum periods. Am J Psychiatry. 2011;168(11):1179-85

16. Rybakowski J., Suwalska K., A., Lojko D., Rymaszewska J., Kiejna A.. Types of depression more frequent in bipolar than in unipolar affective illness: results of the Polish DEP-BI study. Psychopathology, 2007;40(3): 153-158.

17. Azorin J. M., Angst J., Gamma A., Bowden, C. L., Perugi G., Vieta E.,Young A. Identifying features of bipolarity in patients with first-episode postpartum depression: findings from the international BRIDGE study. J Affect Disord.2012; 136(3): 710-715.

18. Vliegen N., Casalin S., Luyten P. (2014). The course of postpartum depression: a review of longitudinal studies. Harv Rev Psychiatry.2014;22(1):1-22.

19. Kammerer M., Marks M. N., Pinard C., Taylor A., von Castelberg B., Künzli H., Glover, V. Symptoms associated with the DSM IV diagnosis of depression in pregnancy and post partum.Arch Womens Ment Health. 2009;12(3):135-141.

20. Pitt B. "Atypical" depression following childbirth. Br. J. Psychiatry, 1968;114(516):1325-1335

21. Hendrick V., Altshuler L., Strouse T., Grosser S. Postpartum and nonpostpartum depression: differences in presentation and response to pharmacologic treatment. Depress Anxiety. 2000;11(2):66-72.

22. Bernstein I. H., Rush A. J., Yonkers K., Carmody T. J., Woo A., McConnell K.,Trivedi, M. H.. Symptom features of postpartum depression: are they distinct?. Depress Anxiety.2008; 25(1):20-26.

23. Beck C. T.,Indman P. The many faces of postpartum depression. J Obstet Gynecol Neonatal Nurs.2005;34(5):569-576.

24. Dalton K.. Depression after delivery . Oxford, UK: Oxford University Press 1996

25. Lindahl V., Pearson J. L.,Colpe L. Prevalence of suicidality during pregnancy and the postpartum.Arch Womens Ment Health. 2005;8(2):77-87.

26. Howard L. M., Flach C., Mehay A., Sharp D.,Tylee A.. The prevalence of suicidal ideation identified by the Edinburgh Postnatal Depression Scale in postpartum women in primary care: findings from the RESPOND trial. BMC Pregnancy Childbirth, 2011; 3(11):57.

27. Johannsen B. M. W., Larsen J. T., Laursen T. M., Bergink V., Meltzer-Brody S., Munk-Olsen T. (2016). All-cause mortality in wom- en with severe postpartum psychiatric disorders. Am J Psychiatry.2016;3 (in press).

28. Wisner K. L., Peindl K. S., Hanusa B. H. Obsessions and compulsions in women with postpartum depression.J Clin Psychiatry 1999;60(3):176-80

29. Wisner K. L., Peindl K. S., Hanusa B. H. Psychiatric episodes in women with young children. J Affect Disord.1995;34(1),:1-11.

30. Barr J. A., \& Beck C. T. Infanticide secrets Qualitative study on postpartum depression. Can Fam Physician, 2008;54(12):17161717.

31. Beck C. T., Records K., Rice M. Further Development of the Postpartum Depression Predictors Inventory-Revised. J Obstet Gynecol Neonatal Nurs 2006;35(6), 735-745.

32. Webster J., Pritchard M. A., Creedy D., East, C. A simplified predictive index for the detection of women at risk for postnatal depression.Birth, 2003;30(2):101-108.

33. Krzyżanowska-Zbucka J. Problemy emocjonalne kobiet w okresie okołoporodowym. Fundacja Rodzić po Ludzku, Warszawa, 2008

34. Kettunen P., Koistinen E., Hintikka J. Is postpartum depression a homogenous disorder: time of onset, severity, symptoms and hopelessness in relation to the course of depression. BMC Pregnancy and Childbirth, 2014;10(14):402

35. Austin M. P., Tully L., Parker G. Examining the relationship between antenatal anxiety and postnatal depression. J. Affect Disord.2007;101(1):169-174.

36. Lee A. M., Lam S. K., Lau S. M. S. M., Chong C. S. Y., Chui H. W., Fong D. Y. T. Prevalence, course, and risk factors for antenatal anxiety and depression. Obstet Gynecol. 2007;110(5):1102-1112.

37. Huizink A. C., Mulder E. J., de Medina, P. G. R., Visser G. H.,Buitelaar J. K. Is pregnancy anxiety a distinctive syndrome?. Early Human Dev.2004; 79(2):81-91.

38. Smith-Nielsen J., Steele H., Mehlhase H., Cordes K., Steele M., Harder S.,Væver M. S. Links Among High EPDS Scores, State of Mind Regarding Attachment, and Symptoms of Personality Disorder. J Pers Disord, 2015;29(6):771-793.

39. Apter G., Devouche E., Gratier M., Valente M., Le Nestour A. (2012). What lies behind postnatal depression: is it only a mood disorder?. J Pers Disord.2012;26(3), 357.

40. Fonseca A., Gorayeb R., Canavarro M. Women C.' help-seeking behaviours for depressive symptoms during the perinatal period: Socio-demographic and clinical correlates and perceived barriers to seeking professional help. Midwifery, 2015;31(12):1177-1185.

41. Dennis C. L., Chung Lee L. Postpartum depression help-seeking barriers and maternal treatment preferences: A qualitative systematic review. Birth, 2006;33(4):323-331.

42. Goodman J. H. Women's attitudes, preferences, and perceived barriers to treatment for perinatal depression. Birth, 2009;36(1):60-69.

43. Bilszta J., Ericksen J., Buist A., Milgrom J. Women's experience of postnatal depression-beliefs and attitudes as barriers to care. Austalian Journal of Advanced Nursing. 2010;27(3):44-

44. Horowitz A., Cousins A. Postpartum depression treatment rates for at-risk women. Nurs Res. 2006:55(2):23-27.

45. Hendrick V., Altshuler L., Strouse T., \& Grosser S.. Postpartum and nonpostpartum depression: differences in presentation and response to pharmacologic treatment. Depress Anxiety, 2000;11(2):66-72.

46. De Crescenzo F., Perelli F., Armando M., Vicari S. Selective serotonin reuptake inhibitors (SSRIs) for post-partum depression (PPD): a systematic review of randomized clinical trials. J Affect Disord.2014;152, 39-44. 
47. Molyneaux E., Howard L. M., McGeown H. R., Karia A. M., Trevillion K. Antidepressant treatment for postnatal depression. Advances in Psychiatric Treatment, 2014; 20(6):368-368.

48. Sharma V., Sommerdyk C. Are antidepressants effective in the treatment of postpartum depression? A systematic review. Prim. Care Companion CNS Disord. 2013;15 (6) PCC-13r01529.

\section{Correspondence address}

Aneta Gerhant

II Klinika Psychiatrii i Rehabilitacji Psychiatrycznej

Uniwersytetu Medycznego w Lublinie

ul. Głuska 2 , 20-439 Lublin

a_gerhant@op.pl

Otrzymano: 20.04.2016

Zrecenzowano: 30.06 .2016

Przyjęto do druku: 07.09.2016 